\title{
Effect of Cyclosporine and Tacrolimus on Cytochrome P450 Activities in Human Liver Microsomes
}

\author{
Toshiro Niwa, ${ }^{*, a}$ Sachiko Yamamoto, ${ }^{b}$ Miho Saito, ${ }^{b}$ \\ Toshifumi SHIRAGA, ${ }^{c}$ and Akira TAKAGI ${ }^{a}$ \\ aPost Marketing Product Development, Astellas Pharma Inc., 3-4-7 Doshomachi, Chuo-ku, Osaka 541-8514, Japan, \\ ${ }^{b}$ Astellas Research Services Co., Ltd., 2-1-6 Kashima, Yodogawa-ku, Osaka 532-8514, Japan, and \\ ${ }^{c}$ Drug Metabolism Research Laboratories, Astellas Pharma Inc., 1-1-8 \\ Azusawa, Itabashi-ku, Tokyo 174-8511, Japan
}

(Received July 20, 2006; Accepted September 30, 2006; Published online October 16, 2006)

\begin{abstract}
The effects of cyclosporine and tacrolimus on cytochrome P450 (CYP) 1A2-mediated 7-ethoxyresorufin $O$-deethylation, CYP2C9-mediated tolbutamide hydroxylation, CYP2C19-mediated $S$-mephenytoin 4'-hydroxylation, CYP2D6mediated debrisoquine 4-hydroxylation, CYP2E1-mediated chlorzoxazone 6-hydroxylation, CYP3A4-mediated nifedipine oxidation, and CYP3A4-mediated testosterone $6 \beta$-hydroxylation activities in human liver microsomes were compared. Cyclosporine and tacrolimus, at concentrations of 0.2 or $2 \mu \mathrm{M}$, neither inhibited nor stimulated any of the metabolic activities except for those of CYP3A4. On the other hand, cyclosporine and tacrolimus competitively inhibited CYP3A4-mediated nifedipine oxidation activity, with inhibition constants $\left(\mathrm{K}_{\mathrm{i}}\right)$ of 1.42 and $0.36 \mu \mathrm{M}$, respectively. In addition, $20 \mu \mathrm{M}$ cyclosporine inhibited CYP2C19 and CYP2D6 activities by $29 \%$ and $30 \%$, respectively. These results suggest that tacrolimus would not cause clinically significant interactions with other drugs, which are metabolized by CYPs, via the inhibition of hepatic metabolism and that the reason why cyclosporine, but not tacrolimus, has a pharmacokinetic inhibitory effect might be that the dosage and/or the unbound concentrations around its metabolic enzymes are higher than those of tacrolimus, rather than the differences in the inhibition potential. Obvious substrate-dependent effects on CYP3A4-inhibition potential were not observed.
\end{abstract}

Key words_— cyclosporine; tacrolimus; cytochrome P450; calcineurin inhibitor; human liver microsomes

\section{INTRODUCTION}

Cytochrome P450s (CYPs) comprise a superfamily of enzymes that catalyze the oxidation of a wide variety of xenobiotic chemicals, including drugs and carcinogens. ${ }^{1-3)}$ Multiple drug therapy is a common therapeutic practice, particularly in patients with several diseases or conditions, and, as a results, many drug-drug interactions involving metabolic inhibition are being reported. ${ }^{4,5)}$

Calcineurin inhibitors, cyclosporine (INN: ciclosporin) and tacrolimus, are the primary immunosuppressants widely used to prevent acute rejection following solid organ transplantation, and both cyclosporine and tacrolimus are metabolized predominantly by CYP3A4. ${ }^{6,7)}$ In most case, the immunosuppressants are co-administered with drugs such as antibiotics, corticosteroids, 3-hydroxy-3methylglutaryl coenzyme A reductase inhibitors, and the possibility of interactions between them and other drugs exist. It is well known that the metabolism of cyclosporine and tacrolimus decrease when they are co-administered with drugs that act as substrates and/ or inhibitors for CYP3A4. ${ }^{8,9)}$ In addition, cyclosporine enhances the plasma concentrations of several drugs such as atorvastatin and repaglinide, which are metabolized by CYP3A4, whereas tacrolimus has no effect on atorvastatin pharmacokinetics (Table 1). ${ }^{10-16)}$ However, there are few in vitro studies comparing the effects of the immunosuppressants on human hepatic CYP-mediated drug-metabolizing activity under the same experimental conditions.

In this study, the effects of cyclosporine and tacrolimus on specific activities by main CYPs, such as CYP1A2, CYP2C9, CYP2C19, CYP2D6, CYP2E1, and CYP3A4, in human liver microsomes were compared under the same experimental conditions in order to clarify the reason(s) for the differences in the in vivo drug interactions between cyclosporine and tacrolimus.

\footnotetext{
*e-mail: toshiro.niwa@jp.astellas.com
} 
Table 1. Drug Interaction of Cyclosporine and Tacrolimus in a Clinical Study

\begin{tabular}{|c|c|c|c|c|c|c|c|c|}
\hline \multirow{2}{*}{ Drug } & \multirow{2}{*}{$\operatorname{Dose}^{a)}$} & \multirow{2}{*}{ Co-medication } & \multirow{2}{*}{$\begin{array}{l}\text { Primary metabolic } \\
\text { enzyme or } \\
\text { transporter }\end{array}$} & \multicolumn{4}{|c|}{$\begin{array}{l}\text { Pharmacokinetic effect }{ }^{b)} \\
(\% \text { of control })\end{array}$} & \multirow{2}{*}{ References } \\
\hline & & & & $C_{\max }$ & AUC & $C_{\text {trough }}$ & $t_{1 / 2}$ & \\
\hline \multirow[t]{5}{*}{ Cyclosporine } & $\begin{array}{l}2.5 \mathrm{mg} / \mathrm{kg} / \mathrm{day} \\
(\text { bid }), 1 \mathrm{day}, p o\end{array}$ & Atorvastatin & CYP3A4 & $(1366)$ & $(1531)$ & $(629)$ & - & $\begin{array}{l}\text { Lemahieu et al. } \\
(2005)^{10)}\end{array}$ \\
\hline & $100 \mathrm{mg}, 2$ days, $p o$ & Repaglinide & $\mathrm{CYP} 3 \mathrm{~A} 4>\mathrm{CYP} 2 \mathrm{C} 8$ & 175 & 244 & - & 97 & $\underset{(2005)^{11)}}{\text { Kajosaari et al. }}$ \\
\hline & $2.5 \mathrm{mg} / \mathrm{kg} /$ day, $p o$ & Diltiazem & CYP3A4 & $(90)$ & $\begin{array}{l}(100) \\
{[N I]}\end{array}$ & $(87)$ & - & Asberg et al. (1999) ${ }^{12)}$ \\
\hline & $\begin{array}{l}\text { Kidney transplant } \\
\text { patient }\end{array}$ & & & & & & & \\
\hline & $5 \mathrm{mg} / \mathrm{kg}, 1$ day, $p o$ & $\begin{array}{l}\text { Micafungin } \\
\text { (1-h infusion) }\end{array}$ & Multiple enzymes & - & $\begin{array}{l}114 \\
{[\mathrm{NI}]}\end{array}$ & - & $\begin{array}{r}(100) \\
{[\mathrm{NI}]}\end{array}$ & $\begin{array}{l}\text { Hebert et al. } \\
\left.(2005 \mathrm{a})^{13}\right)\end{array}$ \\
\hline \multirow[t]{4}{*}{ Tacrolimus } & $\begin{array}{l}0.0625 \mathrm{mg} / \mathrm{kg} / \text { day } \\
\text { (bid), } 1 \text { day, po }\end{array}$ & Atorvastatin & CYP3A4 & $\begin{array}{l}(133) \\
{[\mathrm{NI}]}\end{array}$ & $\begin{array}{l}(112) \\
{[\mathrm{NI}]}\end{array}$ & $\begin{array}{l}(141) \\
{[\mathrm{NI}]}\end{array}$ & - & $\begin{array}{l}\text { Lemahieu et al. } \\
(2005)^{10)}\end{array}$ \\
\hline & po & Cyclosporine & CYP3A4 & - & - & - & - & $\begin{array}{l}\text { A prolongation of } t_{1 / 2} \\
\text { for cyclosporine elimi- } \\
\text { nation was noted in the } \\
\text { patients who received } \\
\text { both cyclosporine and } \\
\text { tacrolimus. }\end{array}$ \\
\hline & & & & & & & & $\underset{(1990)}{\text { Fung })^{14} \text {.J. et al. }}$ \\
\hline & $5 \mathrm{mg}, 1$ day, $p o$ & $\begin{array}{l}\text { Micafungin } \\
\text { (1-h infusion) }\end{array}$ & Multiple enzymes & - & $\begin{array}{l}(99) \\
{[\mathrm{NI}]}\end{array}$ & - & $\begin{array}{l}(93) \\
{[\mathrm{NI}]}\end{array}$ & Hebert et al. (2005b) ${ }^{15)}$ \\
\hline \multirow[t]{3}{*}{$\begin{array}{l}\text { Cyclosporine } \\
\text { /tacrolimus }\end{array}$} & $\begin{array}{l}\text { Cyclosporine: } 2.84 \\
\mathrm{mg} / \mathrm{kg} \text { /dose, } \text { bid, po }\end{array}$ & Sirolimus & CYP3A4, MDR1 & $142^{*}$ & $146^{*}$ & $142^{*}$ & - & Wu et al. $(2005)^{16)}$ \\
\hline & $\begin{array}{l}\text { Tacrolimus: } 0.07 \mathrm{mg} / \\
\mathrm{kg} / \text { dose, } \text { bid, po }\end{array}$ & & & & & & & \\
\hline & $\begin{array}{l}\text { Kidney transplant } \\
\text { patient }\end{array}$ & & & & & & & \\
\hline
\end{tabular}

a) Healthy volunteer, except where indicated. $b$ ) Values in parentheses show the values calculated from the mean $C_{\max }$, AUC, $C_{\text {trough }}$, or $t_{1 / 2}$ values described in the paper. NI: No pharmacokinetic interaction. ${ }^{*}$ Ratio of the cyclosporine group: tacrolimus group.

\section{MATERIALS AND METHODS}

Materials Pooled human liver microsomes from 50 individuals (lot no. 0310241) were obtained from XenoTech (Lenexa, KS, U.S.A.) . Cyclosporine and tacrolimus were prepared by Astellas Pharma Inc. Resorufin, 7-ethoxyresorufin, tolbutamide, debrisoquine sulfate, chlorzoxazone, and nifedipine were obtained from Sigma Chemical Co. (St. Louis, MO, U.S.A.). S-Mephenytoin, 4'-hydroxymephenytoin, oxidized nifedipine, and $6 \beta$-hydroxytestosterone were purchased from Ultrafine Chemicals (Manchester, UK), and hydroxytolbutamide, 4-hydroxydebrisoquine, and 6-hydroxychlorzoxazone from Sumitomo Chemical Co., Ltd. (Tokyo, Japan). Testosterone, phenobarbital sodium, and $p$-hydroxybenzoic acid isopropyl were obtained from Nacalai Tesque (Kyoto, Japan), Wako Pure Chemicals (Osaka, Japan), and Tokyo Chemical Industry (Tokyo, Japan), respectively.
Determination of Human CYP Activity 7Ethoxyresorufin $O$-deethylation activity (CYP1A2), tolbutramide hydroxylation activity (CYP2C9), $S$ mephenytoin 4'-hydroxylation activity (CYP2C19), debrisoquine 4-hydroxylation activity (CYP2D6), chlorzoxazone 6-hydroxylation activity (CYP2E1), nifedipine oxidation activity (CYP3A4), and testosterone $6 \beta$-hydroxylation activity (CYP3A4) in human liver microsomes in the presence or absence of calcineurin inhibitors were determined as described previously. ${ }^{17,18)}$ Briefly, the incubation mixture consisted of human microsomes, $2 \mathrm{mM} \mathrm{NADP}{ }^{+}, 10 \mathrm{mM}$ glucose-6-phosphate, $5 \mathrm{~mm}$ magnesium chloride, 1 unit/ml of glucose-6-phosphate dehydrogenase, 100 $\mathrm{mM}$ phosphate buffer ( $\mathrm{pH} 7.4$ ), and $5 \mu \mathrm{l}$ of methanol or $0.02-2 \mathrm{mM}$ calcineurin inhibitors dissolved in methanol in a final volume of $500 \mu \mathrm{l}$. The microsomal protein concentration in the mixture was 0.05 (for nifedipine oxidation), 0.1 (for 7-ethoxyresorufin $O$ deethylation and testosterone $6 \beta$-hydroxylation) , 0.2 
(for chlorzoxazone 6-hydroxylation), or $0.5 \mathrm{mg} / \mathrm{ml}$ (for tolbutamide hydroxylation, $S$-mephenytoin 4'-hydroxylation, and debrisoquine 4-hydroxylation) ${ }^{17,18)}$ Because the $K_{\mathrm{m}}$ values for 7-ethoxyresorufin $O$-deethylation, tolbutamide hydroxylation, $S$ mephenytoin 4'-hydroxylation, debrisoquine 4-hydroxylation, chlorzoxazone 6-hydroxylation, nifedipine oxidation, and testosterone $6 \beta$-hydroxylation by human liver microsomes were 0.22 , 150.8, 27.3, 83.9, $47.7,12.2$, and $50.3 \mu \mathrm{M},{ }^{17,18)}$ respectively, the concentrations of 7-ethoxyresorufin, tolbutamide, $S$-mephenytoin, debrisoquine, chlorzoxazone, nifedipine, and testosterone were $0.25,200,30,100,50,10$, and $50 \mu \mathrm{M}$, respectively, which are around the expected values for $K_{\mathrm{m}}$. Incubation was carried out at $37^{\circ} \mathrm{C}$ for $5 \mathrm{~min}$ (for testosterone $6 \beta$-hydroxylation), $10 \mathrm{~min}$ (for 7-ethoxyresorufin $O$-deethylation, chlorzoxazone 6-hydroxylation, and nifedipine oxidation), 30 min (for tolbutamide hydroxylation and $S$-mephenytoin $4^{\prime}$-hydroxylation), or $60 \mathrm{~min}$ (for debrisoquine 4-hydroxylation).$^{17,18)}$ In preliminary experiments, the linearity of the reaction with regard to incubation time and protein concentration was confirmed for each assay condition.

Data Analysis All data were analyzed using the average of duplicate or triplicate determinations, and the inhibition constant $\left(K_{\mathrm{i}}\right)$ was estimated by fitting the inhibition curves to Eq. 1 or Eq. 2, when the inhibition type was competitive or noncompetitive, respectively:

$$
\begin{gathered}
v=V_{\text {max }} \cdot S /\left\{K_{\mathrm{m}}\left(1+\mathrm{I} / K_{\mathrm{i}}\right)+S\right\} \\
v=\left\{V_{\max } /\left(1+\mathrm{I} / K_{\mathrm{i}}\right) \cdot S\right\} /\left(K_{\mathrm{m}}+S\right)
\end{gathered}
$$

where $v, S, I, V_{\max }$, and $K_{\mathrm{m}}$ are the velocity of the metabolite formation and the concentrations of substrate and inhibitor, the maximum velocity of the metabolite formation, and the apparent MichaelisMenten constant, respectively. These equations were fitted to data by means of a computer program (MULTI) , 19) and the fit was evaluated using Akaike's information criterion. ${ }^{20)}$

\section{RESULTS}

The inhibitory effects of cyclosporine and tacrolimus at concentrations of 0.2 and $2 \mu \mathrm{M}$ on metabolic activities in human liver microsomes are shown in Fig. 1. Because the maximum blood concentrations $\left(C_{\max }\right)$ of cyclosporine after intravenous or oral dosing are more than 20 times higher than those of tacrolimus, ${ }^{21-25)}$ the inhibitory effects of $20 \mu \mathrm{M}$ cy- closporine was also estimated. Cyclosporine and tacrolimus neither inhibited nor stimulated any of the metabolic activities except that $20 \mu \mathrm{M}$ cyclosporine inhibited CYP2C19 and CYP2D6 activities by 29\% and $30 \%$, respectively, and that both cyclosporine and tacrolimus inhibited CYP3A4-mediated nifedipine oxidation and testosterone $6 \beta$-hydroxylation activities. Therefore, the effects on CYP3A4-mediated nifedipine oxidation activity were investigated in detail (Fig. 2). Cyclosporine and tacrolimus competitively inhibited the CYP3A4 activity, with $K_{i}$ values of 1.42 and $0.36 \mu \mathrm{M}$, respectively. Because cyclosporine was not soluble in the reaction mixture at concentrations over $40 \mu \mathrm{M}$, the effects of cyclosporine on CYP2C19 and CYP2D6 could not be investigated in detail.

\section{DISCUSSION}

This study compared the effects of cyclosporine and tacrolimus on CYP activities under the same experimental conditions. It was demonstrated that the only influence cyclosporine or tacrolimus had on any metabolic activities was that cyclosporine inhibited CYP2C19 and CYP2D6 activities by 30\% at a concentration of $20 \mu \mathrm{M}$, and that both drugs competitively inhibited CYP3A4-mediated nifedipine oxidation activity with $K_{i}$ values of 1.42 and $0.36 \mu \mathrm{M}$, respectively (Figs. 1 and 2, Table $2^{9,10,26-32)}$ ). These results in the effects of tacrolimus on support the results of the previous study which found that tacrolimus has no effect on CYP1A2, CYP2C9,CYP2D6, CYP2E1, and CYP3A4 at concentrations below $1 \mu \mathrm{M}$, but it has a slightly competitive inhibitory effect on CYP3A4 activity, with $K_{i}$ values of $2-3.7 \mu \mathrm{M}$, which suggests that tacrolimus is unlikely to potentiate the effect of co-administered drugs through inhibition of hepatic metabolism. ${ }^{31)}$ In addition, the $K_{i}$ values of cyclosporine and tacrolimus against CYP3A4-mediated estradiol 2-hydroxylation are reported to be 0.30 and $0.88 \mu \mathrm{M}$, respectively. ${ }^{27)}$ Since substrate-dependent effects on CYP3A4-inhibition potential have been reported previously, ${ }^{26,29)}$ this study focused on the estimation of the degree of the CYP3A4-inhibition by the use of other typical CYP3A4-substrates, nifedipine and testosterone. Although we have demonstrated that the $K_{i}$ value for cyclosporine against CYP3A4-mediated nifedipine oxidation activity was approximately 4 times higher than that of tacrolimus, the observed $K_{i}$ and $\mathrm{IC}_{50}$ values of cyclosporine and 

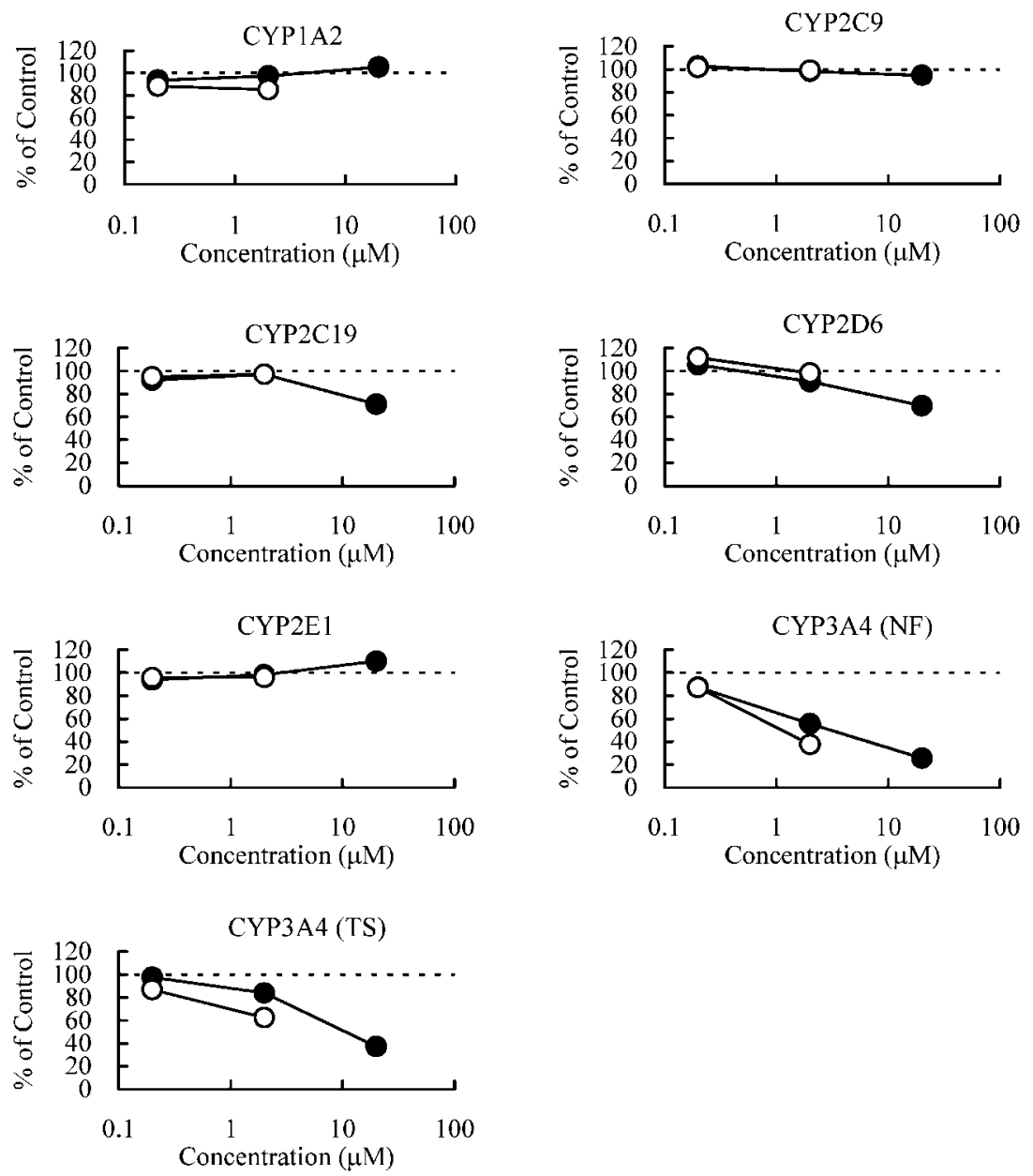

Fig. 1. Effect of Cyclosporine and Tacrolimus on CYP Activities in Human Liver Microsomes

-: Cyclosporine, O: tacrolimus, NF: nifedipine oxidation, TS: testosterone $6 \beta$-hydroxylation.

tacrolimus reported here and elsewhere were around 1 $-4 \mu \mathrm{M}$. The one exception to this was a report that stated that cyclosporine metabolism and tacrolimus 13-O-demethylation were inhibited by tacrolimus and cyclosporine, respectively, with $K_{i}$ values of $37 \mu \mathrm{M}$ (Table 2). That is, obvious substrate-dependent effects on CYP3A4-inhibition potential were not observed.

The initial therapeutic doses of cyclosporine administered by intravenous infusion or oral dosing after organ transplantation in Japan are $3-6 \mathrm{mg} / \mathrm{kg}$ / day and $3-8 \mathrm{mg} / \mathrm{kg} \mathrm{bid}$, respectively, and those of tacrolimus are $0.03-0.1 \mathrm{mg} / \mathrm{kg} /$ day and $0.03-0.15$ $\mathrm{mg} / \mathrm{kg}$ bid, respectively. This indicates that the clinical therapeutic doses of cyclosporine are 30-167 times higher than those of tacrolimus. The clinical maximum blood concentrations $\left(C_{\max }\right)$ after intravenous or oral dosing of cyclosporine and tacrolimus have been reported as $759-1801 \mathrm{ng} / \mathrm{ml}$ and 12.7
$-78 \mathrm{ng} / \mathrm{ml}$, respectively, ${ }^{21-26)}$ that is, around $1-2$ $\mu \mathrm{M}$ and $0.02-0.1 \mu \mathrm{M}$, respectively. No inhibition of human CYPs, except for CYP3A4, by tacrolimus at 2 $\mu \mathrm{M}$ concentration, which is more than 20 times greater than the expected $C_{\max }$, was observed. When the substrate concentration was much lower than the $K_{m}$ value, the ratio of intrinsic metabolic clearance $\left(\mathrm{CL}_{\mathrm{int}}\right)$ in the presence and absence of the inhibitor can be expressed by the following equation, independent of the inhibition type, except in the case of uncompetitive inhibition, ${ }^{33,34)}$

$$
\begin{aligned}
& \left.\mathrm{CL}_{\text {int }}(+ \text { Inhibitor }) / \mathrm{CL}_{\text {int }} \text { (- Inhibitor }\right) \\
& \quad=1 /\left(1+I_{\mathrm{u}} / K_{\mathrm{i}}\right)
\end{aligned}
$$

where $I_{\mathrm{u}}$ is the unbound concentration of the inhibitor. Additionally, when the absorption rate is maximum, the maximum concentration of the inhibitor in the blood flowing into the liver $\left(I_{\text {in,max }}\right)$ after oral dosing can be expressed as

$$
I_{\mathrm{in}, \max }=I_{\mathrm{b}, \max }+\left\{\left(k_{\mathrm{a}} \cdot D / Q_{\mathrm{H}}\right) \cdot F_{a}\right\}
$$



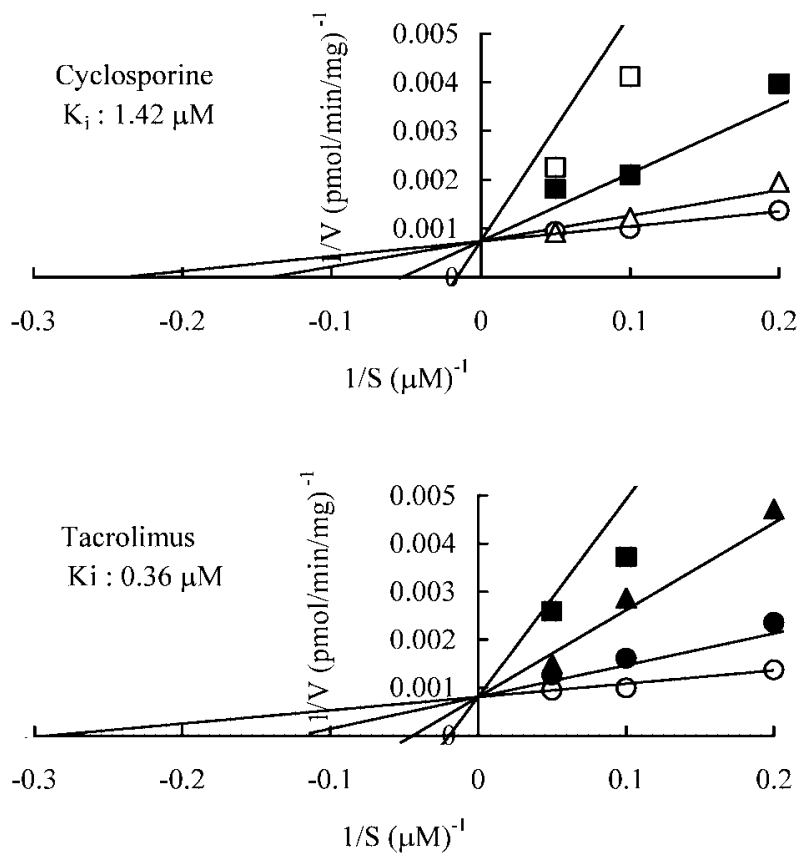

Fig. 2. Effect of Cyclosporine and Tacrolimus on CYP3A4mediated Nifedipine Oxidation Activity in Human Liver Microsomes

The cyclosporine or tacrolimus concentrations were $0 \mu \mathrm{M}(\bigcirc), 0.5 \mu \mathrm{M}$ ), $1 \mu \mathrm{M}(\triangle), 2 \mu \mathrm{M}(\mathbf{\Delta}), 5 \mu \mathrm{M}(\mathbf{\square})$, or $20 \mu \mathrm{M}(\square)$.

where $I_{\mathrm{b}, \max }, k_{\mathrm{a}}, D, Q_{\mathrm{H}}$, and $F_{a}$ represent the maximum blood concentration of the inhibitor in the circulation, the absorption rate constant, the dose, the hepatic blood flow rate, and the fraction absorbed from the gastrointestinal tract into the portal vein, respectively. After an oral dose(s) of $90.3 \mathrm{mg}$ cyclosporine or $0.16 \mathrm{mg} / \mathrm{kg}$ (body weight: $57.4 \mathrm{~kg}$ ) tacrolimus, the peak blood concentrations $\left(I_{\mathrm{b}, \max }\right)$ are expected to be $979 \mathrm{ng} / \mathrm{ml}(0.81 \mu \mathrm{M})$ or $44 \mathrm{ng} / \mathrm{ml}$ $(0.05 \mu \mathrm{M})$, respectively. ${ }^{23,24)}$ The unbound concentrations of $I_{\mathrm{in}, \max }\left(I_{\mathrm{u}, \text { in, max }}\right)$ for cyclosporine and tacrolimus after an oral dosing were calculated to be $78 \mathrm{~nm}$ and $0.16 \mathrm{nM}$, respectively, using the following values: free fraction present in the plasma $\left(f_{\mathrm{u}}\right)=0.015$ and $0.011,35,36)$ blood to plasma concentration ratio $\left(R_{\mathrm{B}}\right)$ $=1.05$ and 52.9, ${ }^{36,37)}$ respectively, $k_{a}=0.1 \mathrm{~min}^{-1}, Q_{\mathrm{H}}$ $=1610 \mathrm{ml} / \mathrm{min}$, and where $F_{a}=1$ to avoid false-negative predictions. In this paper, it was demonstrated that cyclosporine and tacrolimus did not inhibit human CYPs (except CYP3A4) at concentrations of 2 $\mu \mathrm{M}$ or more (Table 1 ), which is 26 - and 12500 -fold higher, respectively, than the predicted $I_{\mathrm{u} \text {, in, max }}$ values. In addition, the $1+I_{\mathrm{u}, \text { in, } \max } / K_{i}$ values of cyclosporine and tacrolimus for CYP3A4-mediated nifedipine oxidation were 1.05 and 1.0004 , respective- ly. Based on these estimations, it was speculated that, after intravenous or oral dosing, these calcineurin inhibitors would not cause clinically significant interactions with any other drugs metabolized by CYPs, via the inhibition of hepatic metabolism. It has been shown that the pharmacokinetics of atorvastatin are not affected by tacrolimus. ${ }^{10)}$ Although tacrolimus reportedly prolongs the half-life of cyclosporine elimination, ${ }^{14)}$ there have been few clinical reports that tacrolimus increases the blood concentrations of other CYP-metabolized drugs as a result of its inhibition of metabolism (Table 1), The mechanism of this cyclosporine-tacrolimus interaction is not clear, but it has led to the prohibition of their concomitant use.

In contrast, cyclosporine enhances the plasma concentrations of CYP3A4 substrates, such as atorvastatin and repaglinide (Table 1). ${ }^{10,11)}$ In addition, the presence of cyclosporine increases the AUC values of lovastatin and pravastatin are 20- and 5-fold, respectively. This suggests that interaction with cyclosporine has a higher impact on lovastatin pharmacokinetics than those of pravastatin. This is because lovastatin is metabolized by CYP3A4, whereas the major pravastatin metabolites are generated by non-CYPdependent processes. ${ }^{38,39)}$ The AUC of bosentan nearly doubled after seven days of co-administration with cyclosporine, but the AUC values of cyclosporine were the same for doses with and without bosentan. ${ }^{40)}$ Bosentan is metabolized by CYP3A4 and CYP2C9, but it also induces these CYPs. ${ }^{41)}$ The interaction observed between bosentan and cyclosporine in clinical trials also occurs in rats, the major determinant of which seems to be the inhibition of active uptake of bosentan from the blood into the liver (liver transport processes). ${ }^{42)}$ Furthermore, the $C_{\max }, \mathrm{AUC}$, and trough concentrations of sirolimus with cyclosporine were $1.42-1.46$ times higher than those when combined with tacrolimus. ${ }^{16)}$ Sirolimus, cyclosporine, and tacrolimus are all substrates not only for CYP3A4 but also multidrug resistance protein 1 (MDR1). ${ }^{16)}$ Recent studies in rats have been shown that cyclosporine increases the plasma concentration of cerivastatin by inhibiting transporter-mediated hepatic uptake. ${ }^{43)}$ CYP3A4 exists not only in the liver but also in the gut, where it plays an important role in the first-pass metabolism after oral administration of its substrates. ${ }^{44)}$ For these reasons, CYP3A4's contribution to the metabolism and the transport process initiated by MDR1 in the gut in addition to 
Table 2. $K_{\mathrm{i}}$ Values of Cyclosporine and Tacrolimus against Human CYP Activities

\begin{tabular}{|c|c|c|c|c|}
\hline Drug & CYP & Reaction & $\begin{array}{l}K_{\mathrm{i}}^{a)} \underset{(\mu \mathrm{IC}}{\mathrm{IC}} 50^{*} \\
(\mu \mathrm{M})\end{array}$ & References \\
\hline \multirow[t]{20}{*}{ Cyclosporine } & CYP1A2 & 7-Ethoxyresorufin $O$-deethylation & $\mathrm{NI}^{b)}$ & \\
\hline & & 7-Ethoxyresorufin $O$-deethylation & $\mathrm{NI}^{c)}$ & Kenworthy et al. (1999) ${ }^{26)}$ \\
\hline & CYP2C9 & Tolbutamide hydroxylation & $\mathrm{NI}^{b)}$ & \\
\hline & CYP2C19 & $S$-Mephenytoin $4^{\prime}$-hydroxylation & $>20^{*}$ & \\
\hline & CYP2D6 & Debrisoquine 4-hydroxylation & $>20^{*}$ & \\
\hline & CYP2E1 & Chlorzoxazone 6-hydroxylation & $\mathrm{NI}^{b)}$ & \\
\hline & CYP3A4 & Nifedipine oxidation & $1.42(\mathrm{C})$ & \\
\hline & & Tacrolimus 31-O-demethylation & $37(\mathrm{C})$ & Lampen et al. (1995) ${ }^{9)}$ \\
\hline & & Estradiol 2-hydroxylation & $0.30(\mathrm{C})$ & Satoh et al. (2003) 27$)$ \\
\hline & & Estradiol 2-hydroxylation & $0.064^{*}$ & Satoh et al. $(2000)^{28)}$ \\
\hline & & Estradiol 4-hydroxylation & $0.050^{*}$ & Satoh et al. $(2000)^{28)}$ \\
\hline & & 7-Benzoyloxyresorufin $O$-dealkylation & $1.2^{*}$ & Stresser et al. $(2000)^{29)}$ \\
\hline & & Fluorescein formation from dibenzylfluorescein & $3.3^{*}$ & Stresser et al. $(2000)^{29)}$ \\
\hline & & 7-Benzoylouxy-4-trifluoromethylcoumarin $O$-dealkylation & $3.1^{*}$ & Stresser et al. $(2000)^{29)}$ \\
\hline & & $\begin{array}{l}\text { Nifedipine oxidation, testosterone } 6 \beta \text {-hydroxylation, } \\
\text { midazolam } 1^{\prime} \text {-hydroxylation }\end{array}$ & - & $\begin{array}{l}\text { Cyclosporine }(10 \mu \mathrm{M}) \text { inhibits } \\
\text { the activities by } 35-88 \% \text {. }\end{array}$ \\
\hline & & & & Stresser et al. $(2000)^{29)}$ \\
\hline & & $\begin{array}{l}\text { Nifedipine oxidation, testosterone } 6 \beta \text {-hydroxylation, } \\
\text { midazolam } 1^{\prime} \text {-hydroxylation, triazolam } 4 \text {-hydroxylation, }\end{array}$ & 一 & $\begin{array}{l}\text { Cyclosporine }(30 \mu \mathrm{M}) \text { inhibits } \\
\text { the activities by } 68-90 \% .\end{array}$ \\
\hline & & $\begin{array}{l}\text { terfenadine } C \text {-hydroxylation, terfenadine } N \text {-demethyla- } \\
\text { tion, diazepam } N \text {-demethylation, dextromethorphan } N \text { - } \\
\text { demethylation, erythromycin } N \text {-demethylation }\end{array}$ & & Kenworthy et al. (1999) ${ }^{26)}$ \\
\hline & & Methoxymorpholinodoxorubicin metabolism & - & $\begin{array}{l}\text { Cyclosporine }(1 \mu \mathrm{M}) \text { inhibits } \\
\text { the activities by } 45-62 \% .\end{array}$ \\
\hline & & & & Beulz-Riche et al. (2002) ${ }^{30)}$ \\
\hline \multirow[t]{20}{*}{ Tacrolimus } & CYP1A2 & 7-Ethoxyresorufin $O$-deethylation & $\mathrm{NI}^{d)}$ & \\
\hline & & 7-Ethoxyresorufin $O$-deethylation & $\mathrm{NI}^{e)}$ & Lecointre et al. (2002) ${ }^{31)}$ \\
\hline & & 1-Methylxanthine formation from theophylline & $\left.\mathrm{NI}^{f}\right)$ & Matsuda et al. (1996) ${ }^{32)}$ \\
\hline & & 3-Methylxanthine formation from theophylline & $\left.\mathrm{NI}^{f}\right)$ & Matsuda et al. (1996) ${ }^{32)}$ \\
\hline & CYP2A6 & Coumarin 7-hydroxylation & $\mathrm{NI}^{e)}$ & Lecointre et al. $(2002)^{31)}$ \\
\hline & CYP2C9 & Tolbutamide hydroxylation & $\mathrm{NI}^{d)}$ & \\
\hline & & Tolbutamide hydroxylation & $\left.\mathrm{NI}^{e}\right)$ & Lecointre et al. (2002) ${ }^{31)}$ \\
\hline & CYP2C19 & $S$-Mephenytoin $4^{\prime}$-hydroxylation & $\mathrm{NI}^{d}$ & \\
\hline & CYP2D6 & Debrisoquine 4-hydroxylation & $\mathrm{NI}^{d)}$ & \\
\hline & & Dextrophan formation from dextromethorphan & $\mathrm{NI}^{e)}$ & Lecointre et al. $(2002)^{31)}$ \\
\hline & CYP2E1 & Chlorzoxazone 6-hydroxylation & $\mathrm{NI}^{d)}$ & \\
\hline & & Chlorzoxazone 6-hydroxylation & $\mathrm{NI}^{e)}$ & Lecointre et al. $(2002)^{31)}$ \\
\hline & CYP3A4 & Nifedipine oxidation & $0.36(\mathrm{C})$ & \\
\hline & & Estradiol 2-hydroxylation & $0.88(\mathrm{~N})$ & Satoh et al. $(2003)^{27)}$ \\
\hline & & Estradiol 2-hydroxylation & $0.64^{*}$ & Satoh et al. (2003) 27$)$ \\
\hline & & Midazolam 1'-hydroxylation & $3.7(\mathrm{C})$ & Lecointre et al. $(2002)^{31)}$ \\
\hline & & Midazolam 4-hydroxylation & $2(\mathrm{C})$ & Lecointre et al. $(2002)^{31)}$ \\
\hline & & Cyclosporine metabolism & $37(\mathrm{C})$ & Lampen et al. $(1996)^{10)}$ \\
\hline & & Prednisolone $6 \beta$-hydroxylation & - & $\begin{array}{l}\text { Tacrolimus }(10 \mu \mathrm{M}) \text { inhibits } \\
\text { the activity by } 65 \% \text {. }\end{array}$ \\
\hline & & & & Matsuda et al. (1996) ${ }^{32)}$ \\
\hline
\end{tabular}

a) C: Competitive inhibition, N: Non-competitive inhibition. $b$ ) No inhibition was observed at $20 \mu \mathrm{M} . c$ ) No inhibition was observed at $30 \mu \mathrm{M}$. $d$ ) No inhibition was observed at $2 \mu \mathrm{M}$. e) No inhibition was observed at $1 \mu \mathrm{M} . f$ ) No inhibition was observed at $1-100 \mu \mathrm{M}$ concentrations. 
metabolism by CYPs in the liver should be taken into consideration. Further studies are required to assess the degree of the contribution of these processes.

In conclusion, this study suggests that tacrolimus would not cause any clinically significant interactions with other drugs that are metabolized by CYPs, via inhibition of hepatic metabolism. Results also suggest that the reason why cyclosporine but not tacrolimus has an inhibitory effect on pharmacokinetics might be because of the dosage and/or because the unbound concentrations of cyclosporine around the metabolic enzymes and/or MDR1 is higher than that of tacrolimus, not because of the differences between the inhibition potencies.

\section{REFERENCES}

1) Gonzalez F. J., Pharmacol. Ther., 45, 1-38 (1990)

2) Guengerich F. P., FASEB J., 6, 745-748 (1992).

3) Rendic S., Drug Metab. Rev., 34, 83-448 (2002)

4) Lin J. H., Lu A. Y. H., Clin. Pharmacokinet. 35, 361-390 (1998).

5) Huang S.-M., Lesko L. J., Williams R. L., J. Clin. Pharmacol., 39, 1006-1014 (1999).

6) Kelly P., Kahan B. D., Current Drug Metab., 3, 275-287 (2002).

7 ) Venkataramanan R., Swaminathan A., Prasad T., Jain A., Zuckerman S., Warty V., McMichael J., Lever J., Burckart G., Starzl T., Clin. Pharmacokinet., 29, 404-430 (1995).

8) Lampen A., Christians U., Bader A., Hackbarth I., Sewing K.-F., Pharmacology, 52, 159 -168 (1996).

9) Lampen A., Christians U., Guengerich F. P., Watkins P. B., Kolars J. C., Bader A., Gonschior A.-K., Dralle H., Hackbarth I., Sewing K.-F., Drug Metab. Dispos., 23, 1315-1324 (1995) .

10) Lemahieu W. P. D., Hermann M., Asberg A., Verbeke K., Holdaas H., Vanrenterghem Y., Maes B. D., Am. J. Transplant., 5, 2236-2243 (2005)

11) Kojosaari L. I., Niemi M., Neuvonen M., Laitila J., Neuvonen P. J., Backman J. T., Clin. Pharmacol. Ther., 78, 388-399 (2005) .

12) Asberg A., Christensen H., Hartmann A.,
Carlson E., Molden E., Berg K. J., Eur. J. Clin. Pharmacol., 55, 383-387 (1999).

13) Hebert M. F., Townsend R. W., Austin S., Balan G., Blough D. K., Buell D., Keirns J., Bekersky I., J. Clin. Pharmacol., 45, 954-960 (2005) .

14) Fung J. J., Todo S., Jain A., McCauley J., Alessiari M., Scotti C., Starzl T. E., Transplant. Proc., 22, 6-12 (1990).

15) Hebert M. F., Blough D. K., Townsend R. W., Allison M., Buell D., Keirns J., Bekersky I., J. Clin. Pharmacol., 45, 1018-1024 (2005).

16) Wu F. L., Tsai M.-K., Chen R. R., Sun S.-W., Huang J.-D., Hu R.-H., Chen K.-H., Lee P.H., Pharmacotherapy, 25, 646-653 (2005).

17) Niwa T., Shiraga T., Yamasaki S., Ishibashi K., Ohno Y., Kagayama A., Xenobiotica, 33, 717-729 (2003).

18) Niwa T., Inoue, S., Shiraga T., Takagi A., Biol. Pharm. Bull., 28, 188-191 (2005).

19) Yamaoka K., Tanigawara Y., Nakagawa T., Uno T., J. Pharmacobio.-Dyn., 4, 879-885 (1981).

20) Akaike H., Transact. Automat. Control, 19, 716-723 (1974).

21) Follath F., Wenk M., Vozeh S., Thiel G., Brunner F., Loertscher R., Lemaire M., Nussbaumer K., Niederberger W., Wood A., Clin. Pharmacol. Ther., 34, 638-643 (1983).

22) Mueller E. A., Kovarik J. M., van Bree J. B., Grevel J., Lucker P. W., Kutz K., Pharm. Res., 11, 151-155 (1994).

23) Takahara S., Ota K., Ohashi Y., Namii Y., Uchida K., Kainuma H., Takagi H., Takahashi K., Morikawa H., Transplant. Now, 12, 5-24 (1999).

24) Ishibashi M., Fukao K., Takahashi K., Haba T., Uchida K., Takahara S., Iwasaki Y., Ota K., Takagi H., Sonoda T., Ishoku, 29, 294313 (1994).

25) Takahara S., Hatori M., Okuyama A., Transplant. Now, 12, 537-543 (1999).

26) Kenworthy K. E., Bloomer J. C., Clarke S. E., Houston J. B., Br. J. Clin. Pharmacol., 48, 716-727 (1999).

27) Satoh T., Munakata H., Fujita K., Itoh S., Itoh S., Kamataki T., Yoshizawa I., Biol. Pharm. Bull., 26, 695-700 (2003).

28) Satoh T., Fujita K., Munakata H., Itoh S., 
Nakamura K., Kamataki T., Itoh S., Yoshizawa I., Anal. Biochem., 286, 179-186 (2000) .

29) Stresser D. M., Blanchard A. P., Turner S. D., Erve J. C. L., Dandeneau A. A., Miller V. P., Crespi C. L., Drug Metab. Dispos., 28, 1440-1448 (2000).

30) Beulz-Riche D., Robert J., Riche C., Ratanasavanh D., Cancer Chemother. Pharmacol., 49, 274-280 (2002).

31) Lecointre K., Furlan V., Taburet A.-M., Fund. Clin. Pharmacol., 16, 455-460 (2002) .

32) Matsuda H., Iwasaki K., Shiraga T., Tozuka Z., Hata T., Guengerich F. P., Res. Commun. Mol. Pathol. Pharmacol., 91, 57-64 (1996).

33) Ito K., Iwatsubo T., Kanamitsu S., Ueda K., Suzuki H., Sugiyama Y., Pharmacol. Rev., 50, 387-411 (1998).

34) Ito K., Iwatsubo T., Kanamitsu S., Nakajima Y., Sugiyama Y., Ann. Rev. Pharmacol. Toxicol., 38, 461-499 (1998).

35) Yang H., Elmquist W. F., Pharm. Res., 13, 622-627 (1996).

36) Nagase K., Iwasaki K., Nozaki K., Noda K., J. Pharm. Pharmacol., 46, 113-117 (1993) .

37) Zaghloul I., Ptachcinski R. J., Burckart G. J.,
Thiel D. V., Starzel T. E., Venkataramanan, R., J. Clin. Pharmacol., 27, 240-242 (1987).

38) Olbricht C., Wanner C., Eisenhauer T., Kliem V., Doll R., Boddaert M., O’Grady P., Krekler M., Mangold B., Christians U., Clin. Pharmacol. Ther., 62, 311-321 (1997).

39) Kitazawa E., Tamura N., Iwabuchi H., Uchiyama M., Muramatsu S., Takahagi H., Tanaka M., Biochem. Biophys. Res. Commun., 192, 597-602 (1993).

40) Binet I., Wallnofer A., Weber C., Jones R., Thiel G., Kidney International, 57, 224-231 (2000) .

41) Cheng J. W. M., Heart Disease, 5, 161-169 (2003).

42) Treiber A., Schneiter R., Delahaye S., Clozel M., J. Pharmacol., Exp. Ther., 308, 11211129 (2004).

43) Shitara Y., Hirano M., Adachi Y., Itoh T., Sato H., Sugiyama Y., Drug Metab. Dispos., 32, 1468-1475 (2004).

44) Wu C.-Y., Benet L. Z., Hebert M. F., Gupta S. K., Rowland M., Gomez D. Y., Wacher V. L., Clin. Pharmacol. Ther., 58, 492-497 (1995). 